\title{
THREE TYPES OF VERBAL LOGOPHORICITY IN AFRICAN LANGUAGES
}

\author{
Timothy Jowan Curnow \\ La Trobe University
}

\begin{abstract}
The term logophoric is most strongly tied to pronominal systems. However, most recent literature on logophoricity accepts the existence of verbal marking of logophoricity. Through examining the verbal logophoricity which has been reported in African languages, it can be seen that there are three different types of verbal marking: logophoric cross-referencing, first person logophoricity, and verbal logophoric affixation. These different types may appear as the only form of logophoric marking in a language, or they may combine with each other and with logophoric pronouns. Each of these types appears to have distinct properties and, hence, needs to be treated separately in typological literature.
\end{abstract}

\section{Introduction 1}

Since the introduction of the term "logophoric" (logophorique) by Hagège in 1974, our knowledge of this phenomenon has grown greatly. Most recent general works discussing logophoricity [e.g., Culy 1994a, von Roncador 1992, Wiesemann 1986] have allowed that logophoricity may be marked in pronoun systems or through verbal morphology. However, it appears that, rather than a single phenomenon of verbal logophoricity, three distinct types of verbal logophoricity, with different properties, are found in African languages.

After defining logophoricity in section 2, the three types of verbal logophoricity-logophoric cross-referencing, first person logophoricity, and logophoric verb affixes-are discussed individually in sections 3-5, with each being compared to logophoric pronoun systems. Section 6 deals with the possibility of combining more than one logophoric strategy in a single language. Following this, the effect

1 This research was carried out while the author was an Australian Research Council Postdoctoral Fellow. I would like to thank Bob Dixon, Sasha Aikhenvald, Gerrit Dimmendaal, Felix Ameka, Robert Botne, and an anonymous reviewer for their comments, which doubtless improved this paper. 
that the division of verbal logophoricity into three distinct types has on general typological work on logophoricity is discussed.

\section{Logophoricity}

In its original conception, the term logophoric was intended to take account of the patterns of pronominal systems found in many West African languages, and was defined as "a particular category of substitution elements (substituts), personal and possessive, which refer to the author of a discourse or to a participant whose thoughts are reported" [Hagège 1974:287; my translation]. This can be seen in the contrast of object pronouns in the subordinate clauses of examples (1) and (2) taken from the Dogon language Donno So. When there is a reference in the subordinate clause to the original speaker, the logophoric pronoun inyeme occurs, contrasting with the use of the third person pronoun wo when the reference is to some person other than the original speaker. ${ }^{2}$

Donno So [Culy 1994a:1056]

(1) Oumar [Anta wo-ñ waa be] gi

Oumar Anta 3S-OBJ seen AUX said

'Oumari said that Anta ${ }_{\mathrm{j}}$ had seen himk.'

(2) Oumar [Anta inyeme-ñ waa be] gi

Oumar Anta LOG-OBJ seen AUX said

'Oumar ${ }_{i}$ said that Anta ${ }_{j}$ had seen him .' '

Since its original introduction, the term has been extended in a variety of ways. Leaving aside the use of the term in generative literature, where it is often defined in terms of binding properties (see, for example, Reinhart \& Reuland [1991], Reuland [2001]), there is general agreement on the use of the term to indicate some (special) marking in clauses subordinated to verbs of speech (thought, emotion) which distinguishes between reference to the original speaker (thinker, feeler) and other referents; precise details of the definition may, however, vary.

2 Abbreviations used in glosses have been taken from the works cited, except in cases where a gloss was added.

$\begin{array}{llllll}\text { AP } & \text { antipassive } & \text { INDIR } & \text { indirect mode } & \text { PRG } & \text { progressive } \\ \text { AUX } & \text { auxiliary } & \text { INIT } & \text { quote initiator } & \text { PST } & \text { past } \\ \text { COMP } & \text { complementizer } & \text { LOG } & \text { logophoric } & \text { REL } & \text { relativizer } \\ \text { CONN } & \text { connector } & \text { NON1 } & \text { non-first person } & \text { RP } & \text { reporting particle } \\ \text { COP:PRE } & \text { present tense copula } & \text { NPST } & \text { non-past } & \text { S OR SG } & \text { singular } \\ \text { CPL } & \text { complementizer } & \text { OBJ } & \text { object } & \text { SUBJ } & \text { subject } \\ \text { DF } & \text { definite } & \text { P or PL } & \text { plural } & 1 / 2 / 3 & \text { person marking } \\ \text { FACT } & \text { factitive } & \text { PA } & \text { past } & 4 & \begin{array}{c}\text { non-coreferential } \\ \text { third person }\end{array} \\ \text { FUT } & \text { future } & \text { PRT } & \text { particle } & & \\ \text { IN } & \text { inclusive } & \text { POSS } & \text { possessive } & & \end{array}$


In this paper, an element will be considered to be a verbal logophoric marker if it is a verbal form used in clauses embedded under a verb of speech (and potentially under verbs of thought or emotion) which indicates that one of the referents of the subordinate clause (almost always, but not necessarily, the subject) is coreferential with one of the referents of the matrix clause (once again, almost always the subject). Additionally, this form must be grammatically required, that is, obligatory, in the appropriate contexts.

Under this definition, three different types of verbal logophoric markers are found in African languages, depending on whether the logophoric marker contrasts with (other) person marking forms and on whether the logophoric marker is used (for different purposes) in matrix clauses.

\section{Logophoric cross-referencing}

The most straightforward form of logophoric verbal marking is found in languages with verbal cross-referencing for person, where in subordinate clauses of the appropriate type there is an extra cross-referencing form, logophoric crossreferencing.

For example, the Bantu language Akosse, spoken in Nigeria, has verbal prefixes which indicate the person and number of the subject if it is human (for nonhuman subjects, the prefix indicates the noun class of the subject), with distinct prefixes for first, second and third person singular, and first inclusive plural, first (exclusive) plural, second plural and third plural [Hedinger 1981]. As well as these forms, however, there is an additional, distinct, verb prefix used in subordinate clauses embedded under a verb of speech if the subject of the subordinate clause is coreferential with a second or third singular subject in the matrix clause, as seen in example (4). That is, in Akoose there is a verbal affix, contrasting with (other) person-marking affixes, used for indicating logophoricity-this sort of verbal logophoric marking will be referred to as logophoric cross-referencing.

Akoose [Hedinger 1984:95]

(3)

à-hóbé ă á-kàg

he-said RP he-should.go

'He said that he (someone else) should go.'

(4) à-hóbé ă mó-kàg

he-said RP LOG-should.go

'He said that he (himself) should go.'

In Aksose, the logophoric cross-referencing occurs when the matrix subject is second or third person singular. The Nilo-Saharan languages Logo and Kaliko, spoken in the Democratic Republic of Congo (formerly Zaire), also have verb prefixes marking cross-referencing, with third person singular being zero (plus the option of a fully expressed third singular pronoun) as in example (5), and contrasting with a logophoric verb prefix, occurring only with third person 
singular matrix subjects, as in example (6). The closely related language Moru, spoken in Sudan, has a similar system, with the logophoric cross-referencing once again restricted to third person, but with separate forms for singular and plural.

Kaliko [Andersen \& Goyvaerts 1986:313]

(5)

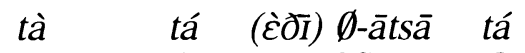

3S.speak CPL he 3S-come CPL

' $\mathrm{He}_{\mathrm{i}}$ said that he $\mathrm{j}_{\mathrm{j}}$ came.'

(6) tà tá yí-ātsā tá drùzùle

3S.speak CPL LOG-come CPL morning

' $\mathrm{He}_{\mathrm{i}}$ said that he $\mathrm{i}_{\mathrm{i}}$ came this morning.'

Logophoric cross-referencing may occur with or without an additional system of logophoric pronouns. Thus, Aksose has a logophoric cross-referencing system but no logophoric pronouns [Hedinger 1984:98], Logo and Kaliko have a logophoric pronoun for third person singular and Moru has logophoric pronouns for third singular and third plural [Andersen \& Goyvaerts 1986]; in Logo, Kaliko, and Moru, the logophoric pronoun form is also used as a reflexive pronoun; interestingly, the logophoric pronoun appears not to be used as a subject form (though the logophoric subject marker is clearly diachronically related to it).

Logophoric cross-referencing systems seem to have the same general typological properties as logophoric pronouns. Logophoric cross-referencing terms form a paradigm with other person-marked terms, just as logophoric pronouns form a paradigm with other (person-marked) pronouns. If a language has a logophoric cross-referencing system, the logophoric term is always used with singular referents, but may (e.g., Moru) or may not (e.g., Logo) be used with plural referents. Similarly, the logophoric term is always used with third person referents, but may (e.g., Akəose) or may not (e.g., Kaliko) be used with second person referents. Both of these distributional properties are found with logophoric pronouns [Hyman \& Comrie 1981, Wiesemann 1986].

Of course, the similarity between logophoric cross-referencing and logophoric pronouns is not surprising. While the above cases of logophoric cross-referencing are clear verbal affixes, several of the examples of logophoric "pronouns" discussed in the literature are intermediate between logophoric pronouns and logophoric cross-referencing, as subject "pronouns" in these languages cliticize to the verb. This occurs, for example, in one of the standard examples of logophoricity, the Kwa language Ewe, spoken in Ghana, where subject pronouns, including the logophoric subject pronoun, cliticize to the following verb, as in examples (7) and (8).

Ewe [Clements 1975:142]

(7) Kofi be e-dzo

Kofi say 3S-leave

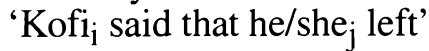


(8) Kofi be yè-dzo

Kofi say LOG-leave

'Kofi $i_{i}$ said that he left' $^{\prime}$

These cliticized (weak subject) forms are often similar to, but not necessarily identical to, the independent (strong) pronoun forms-for example, the independent third singular pronoun is ye, rather than the cliticized $e$ in the Anlo dialect of Ewe [Clements 1975:148]. Given the well-known process of gram-maticalization by which cliticized pronouns become verb affixes, systems of logophoric pronouns can thus become systems of logophoric cross-referencing; and indeed Andersen and Goyvaerts [1986] maintain that the logophoric cross-referencing system of Logo, Kaliko, and Moru has clearly arisen from a grammaticalization of the logophoric/reflexive pronouns to the verb. The system of Akoose, on the other hand, has arisen by other means; Hedinger [1984] maintains it is a grammaticalization of a stressed subject pronoun and the (usual) third person subject marker.

One difference between the behaviour of logophoric pronouns and logophoric cross-referencing arises as a natural consequence of the restricted use of crossreferencing in many languages. While logophoric pronouns can always be found as subject pronouns (and in some languages can only be used as subjects), ${ }^{3}$ logophoric pronouns are also commonly used in other grammatical functions, especially as objects and as possessive forms. Logophoric cross-referencing, on the other hand, is seldom found marking anything other than subjects; but then in the languages in which it occurs, cross-referencing is seldom used for anything other than subject marking. Clearly, logophoric (verbal) cross-referencing cannot be used to mark possessive, and only one language, Mabaan, is known in which logophoric cross-referencing may be used to show a logophoric object.

Mabaan is a Nilo-Saharan language spoken in Sudan. It has a highly complex verbal system, with verbs being marked to agree in person and number with subject and object, and also to indicate tense and mood [Andersen 1999]. It has an "anti-logophoric" system of pronouns: the pronouns which in matrix clauses indicate third person (e.g., singular Ṕ́kè) are used in logophoric domains to indicate coreference with the matrix subject, while a special set of fourth person

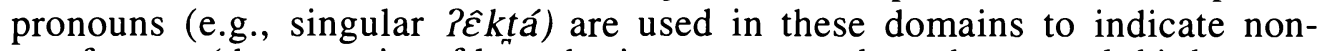
coreference (the opposite of logophoric pronouns, where the normal third person pronouns indicate non-coreference while a special set of logophoric pronouns indicates coreference).

\footnotetext{
3 This is not entirely true, in fact. As was seen in example (8), logophoric subject pronouns may cliticize to the verb. If a language uses logophoric pronouns for subject and non-subject arguments, but then subject pronouns become verbal affixes through cliticization, the resulting system may use logophoric cross-referencing for subject arguments but logophoric pronouns for nonsubject arguments. This is presumably what has happened diachronically in Logo, Moru, and Kaliko, for example, where logophoric pronouns are found for non-subject arguments but there are (historically related) logophoric cross-referencing prefixes for subject arguments [Anderson \& Govaerts 1986].
} 
Mabaan [Andersen 1999:508]

(9) Rékè gókè Pàgē lékè kâyłf́

3S say:AP:3 INIT 3S swim:FUT:INDIR:3S

' $\mathrm{He}_{\mathrm{i}}$ says that he $\mathrm{i}_{\mathrm{i}}$ will swim.'

(10) Rékè gókè Ràgē ?êktá kând̄ó

3S say:AP:3 INIT $4 S^{n}$ swim:FUT:INDIR:4

' $\mathrm{He}_{\mathrm{i}}$ says that he $\mathrm{j}_{\mathrm{j}}$ will swim.'

Just as there are only three person distinctions in pronouns in matrix clauses but four person distinctions in pronouns in clauses subordinated to speech verbs, there are likewise three person distinctions in verb forms in matrix clauses and four person distinctions in verb forms in subordinate clauses; hence, there is a distinc-tion in form between the subordinate verbs in the above two sentences. However, the verb forms used in subordinate clauses (indirect mode) are distinct for all persons from those used in matrix clauses (direct mode), so that corresponding to the subordinate clauses in sentences (9) and (10) above is the matrix clause given in example (11).

Mabaan [Andersen 1999:507]
(11) Tékè kánà
3S swim:FUT:3
'He will swim.'

Thus, unlike (other) examples of logophoric cross-referencing, in Mabaan there is no special logophoric verb form contrasting in subordinate contexts with the usual matrix verb forms, as all subordinate verb forms are distinct from matrix verb forms. In any case, while the system of pronouns is anti-logophoric rather than logophoric, the system of verbal marking of (anti-)logophoricity shows that a subordinate object is coreferential with a matrix subject as easily as showing that a subordinate subject is coreferential with a matrix subject, as can be seen in examples (12) to (14).

Mabaan [Andersen 1999:509]

(12) Tékè gókè Tàgē Tékè ?êktá jònłé

3S say:AP:3 INIT 3S 4S kick:PA:INDIR:3S:4

'He $\mathrm{i}_{\mathrm{i}}$ says that he $\mathrm{i}_{\mathrm{i}}$ has kicked him.

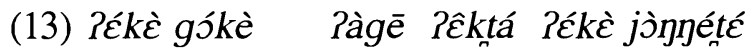

$3 S$ say:AP:3 INIT 4S 3S kick:PA:INDIR:X:3S

'He $\mathrm{H}_{\mathrm{i}}$ says that he $\mathrm{j}_{\mathrm{j}}$ has kicked him $\mathrm{i}_{\mathrm{i}}$.'

(14) Rékè gókè Tàge Têktá Têktá jòndá

3S say:AP:3 INIT $4 \mathrm{~S}^{\curvearrowright}$ 4S kick:PA:INDIR:4S:4

' $\mathrm{He}_{\mathrm{i}}$ says that he $\mathrm{j}_{\mathrm{j}}$ has kicked him $\mathrm{k}$ ' 
Thus, excluding the complex case of Mabaan, the first type of verbal logophoricity, logophoric cross-referencing, appears to be quite similar to the marking of logophoricity using pronouns-there is a special (verb) form used to show that one of the referents of a clause subordinated to a speech verb is coreferential to the subject of the matrix clause (more correctly, the source of the proposition, to take account of matrix clauses such as 'I heard from him that ...' where logophoric marking indicates coreference with 'him'); this special logophoric form contrasts with other person forms; the logophoric marker may be used only with third person referents or with second and third person referents, and it may be used only with singular referents or with singular and plural referents. With the exception of the system of marking of Mabaan, logophoric cross-referencing has only been found indicating coreference of a subordinate subject with a matrix subject, but in languages with logophoric cross-referencing the cross-referencing system in general only marks subject, so this is not surprising.

\section{First person marking as logophoric}

The second type of verbal logophoricity found in African languages is the use of a "first person" verb affix to indicate logophoricity in appropriate contexts. For example, the Dogon language Donno So, spoken in Mali and Burkina Faso, has a logophoric pronoun, inyeme. However, Donno So also has a system of verbal affixation where finite verbs (in matrix clauses) can agree in person and number with their subjects; for example, boje-m 'I'm going', boje-u 'you're going', boje 'she/he is going' [Culy 1994b:122]. In finite subordinate clauses of the appropriate kind with a logophoric subject, the verb is necessarily inflected with the verb suffix which would, in a matrix clause, indicate a first person subject, as seen in example (15).

\section{Donno So [Culy 1994b:123]}

(15)

Oumar [inyeme jembo paza bolum] miñ tagi

Oumar LOG sack:DF drop left:1S 1S:OBJ informed

'Oumar ${ }_{i}$ told me that he ${ }_{i}$ had left without the sack.'

A first person verb form would naturally occur in this context in direct speech, where within the quoted speech the original speaker would be using first person references: 'Oumar told me, "I left without the sack". However, in this case, not only would the verb suffix be first person, but any pronouns in the clause referring to the speaker would also be first person; as seen in example (15), rather than a first person subject pronoun the logophoric pronoun is used in these contexts, showing that such sentences are clearly not examples of direct speech, and consequently that the use of a first person subordinate verb form is unusual. ${ }^{4}$

4 It is, of course, easy to speculate that this system of first person logophoric marking has arisen through the reanalysis of direct speech as indirect speech. This would be particularly common, one assumes, in languages with optional ellipsis of pronouns, since there is then no 
Under certain conditions, Donno So allows the omission of subjects. When this occurs, a subordinate "first person" verb form may be the only indication of subordinate subject logophoricity, as in example (16). Note that the logophoric pronoun in (16) is not a subject pronoun, but rather a part of the object noun phrase, indicating that the field belongs to Oumar; the only indication that the subordinate subject is Oumar is the use of the first person logophoric marking on the subordinate verb.

Donno So [Culy 1994b:123]

(16) Oumar [minne inyeme m̃ gendezem] gi

Oumar field LOG POSS regard:PRG:1S said

'Oumar ${ }_{i}$ said that he $i_{i}$ will look at his ${ }_{i}$ field.'

In a context where a subordinate "first person" verb form could crossreference a logophoric subject, this form may not be used to cross-reference a first person subordinate subject; instead, an unmarked verb form (which is identical to the third person form) must be used together with an explicit first person pronoun, as in example (17).

Donno So [Culy 1994b:123]

(17) Oumar [ma jembo paza boli] miñ tagi

Oumar 1S:SUBJ sack:DF drop left 1S:OBJ informed

'Oumar told me that I had left without the sack.'

In Donno So, this strategy of using subordinate "first person" verb forms to mark a logophoric subject is present together with the existence of a logophoric pronoun. In some other languages, however, the "first person" marking of logophoricity is present, but there is no logophoric pronoun. This is found, for example, in some Nilo-Saharan languages-Lotuko in example (19) and Karimojong in example (18)-where a subordinate clause with a logophoric subject has first person verbal marking, but a third person subject pronoun. It is not known how these languages mark a subordinate verb which has a first person, non-logophoric, subject in a sentence such as 'she said that I went'.

formal distinction between a direct speech "she said "(I) I-go"" and an indirect speech logophoric "she said (she) I-go". In the synchronic system, however, the construction is clearly distinct from direct speech when separate pronoun forms occur in the subordinate clause. It is interesting to note that there were early proposals that logophoric pronouns developed from first person markers [e.g., in Heine \& Reh 1984]. More recent work [e.g., Dimmendaal 2001, von Roncador 1992] has suggested an origin in demonstrative elements, discounting a first person origin. While logophoric pronouns thus seem not to develop from first person marking, this would appear to be the origin of some logophoric verbal marking. 
Karimojong [Novelli 1985:531; gloss added]

\section{(18) àbù papà tolim ebè àlózì inèz morotó}

AUX father say that 1S.go.NPST 3S Moroto

'The father said that he was going to Moroto'

Lotuko [Muratori 1938; quoted in von Roncador 1992:172]

(19) aati 'dan xul ojori 'to jojo era isi a xobwok people all REL say PRT COMP 1P:be they PRT kings

'Those, who say that they are kings'

While relatively little reported, it is possible that this form of logophoric marking is, in fact, much more common. In many African languages, there is no tense shifting, so that an indirect speech complement will contain the same tense/ aspect/mood as the original utterance; both direct speech and indirect speech are often introduced with the same complementizer. If a language has first person logophoricity and optional subject pronouns, then first person logophoricity in indirect speech can easily be mistaken for simple direct speech, as the only indication of the difference occurs with the choice of a pronoun form accompanying a first person verb, either third person or logophoric for indirect speech, or first person for direct speech. If the only examples collected by a researcher have no explicit pronoun forms in the subordinate clause, the use of first person logophoric marking will be mistaken for direct speech.

First person logophoric marking has some similarities with the patterns of distribution of logophoricity marked with logophoric cross-referencing or logophoric pronouns. In particular, the logophoric (first person) verb form contrasts with other person-marked verb forms. However, in contrast to logophoric cross-referencing, there is no special logophoric marking, as the form used is one which would be used to mark first person subjects in matrix clauses.

In Donno So, only third person referents can be referred to using the first person logophoric marking (and also the logophoric pronoun). Likewise, only third person examples have been found for Karimojong and Lotuko. However, it will be seen below in section 6 that the first person strategy may also be used with second person referents, just as with logophoric pronouns and logophoric cross-referencing. The issue of whether it can be used with first person referents is a complex one, since the marking is first person in any case; this will also be looked at in section 6.

Once again just like logophoric cross-referencing, first person logophoric marking has only been found marking subordinate subjects as logophoric. In the case of Donno So, this is all that can be marked, as verbal marking is only used to show person of the subject. In Karimojong, verbs inflect for person of subject and object, but it is not known at this stage if the first person logophoric marking extends to the marking of subordinate objects.

One final distinction which appears between first person logophoric marking and logophoric pronouns (and logophoric cross-referencing) is that first person logophoric marking has never been reported to occur only with singular referents 
- it generally occurs in both singular and plural, and has in fact been found in one or two languages occurring only with plural referents (see section 6).

An alternative analysis to treating first person logophoric marking as a separate phenomenon would, of course, be to consider that these languages have logophoric cross-referencing but that, for whatever reason (e.g., phonetic changes), the logophoric cross-referencing marker is simply homophonous with the first person marking, and this will be considered as a possibility for Efik and Ibibio in section 6 . While no definitive statement can be made on this issue, various arguments can be made against this claim of homophony.

From a theoretical point of view, it is better to treat identical forms in a unitary fashion if possible, rather than as homophonous. This argument seems particularly cogent if, as is the case in Karimojong, each of the two putatively separate forms in the language have precisely the same complex patterns of allomorphy. Furthermore, as will be seen in section 6, Ekpeye has both inclusive and exclusive first person plural markers, and both can be used to mark logophoricity-a truly astonishing case of homophony with related semantics, if it were treated as such.

Another argument against the homophony hypothesis can be seen in Donno So, where the "first person" form cannot be used in subordinate clauses to mark first person if it can be interpreted as being the logophoric form. If this were simple homophony, we would expect that the first person form could be used in these cases, although an explicit pronoun may be needed to disambiguate.

Additionally, of course, there is the slightly distinct pattern of distribution of logophoric cross-referencing and first person logophoricity with singular and plural referents mentioned above.

Thus, it seems that first person logophoricity should be treated as a separate phenomenon from logophoric cross-referencing.

\section{Logophoric verbal affix}

The most commonly discussed example of verbal logophoricity in African languages is the system of the Cross-River (Benue-Congo) language Gokana, based on the data presented in two papers by Hyman and Comrie [1981, 1982]. In this language there is a verbal suffix $-E E$ (with a variety of phonologically conditioned allomorphs) which marks logophoric reference; the contrast between its absence and presence can be seen in sentences (20) and (21). (While from these examples the logophoric verbal suffix looks simply like a same-subject marker, this is not the case, as will be seen in example (22) below.)

Gokana [Hyman \& Comrie 1981:20]

(20) aè ko aè $d j$

he said he fell

' $\mathrm{He}_{\mathrm{i}}$ said that he $\mathrm{j}_{\mathrm{j}}$ fell.' 


\section{(21) aè $k o$ aè $d o-\grave{\varepsilon}$ \\ he said he fell-LOG \\ 'He $\mathrm{H}_{\mathrm{i}}$ said that he $\mathrm{i}_{\mathrm{i}}$ fell.'}

This system of marking logophoricity shares with other systems the environments in which it occurs. However, while Gokana is commonly included in discussions of logophoricity and the development of typologies of logophoric marking [e.g., Culy 1994a, Huang 2000, Hyman \& Comrie 1981, Wiesemann 1986], there are clear differences between the logophoric verbal affix of Gokana and other logophoric systems.

The most obvious of these is that the logophoric marker is not integrated into a system which otherwise marks person, which is the case for logophoric pronouns, logophoric cross-referencing, and first person logophoric marking. In all other cases, the logophoric marking is opposed to some other marking indicating person; in Gokana, the logophoric marker contrasts with its absence, which gives no indication of person.

Another contrast with other systems is that, while the use of the logophoric verbal affix is obligatory with third person referents, it is optional with singular second person referents. Other systems of logophoric marking are obligatory when appropriate in their prototypical use under verbs of speech [Culy 1994a:1080]. In some languages, logophoricity may only be used with third person referents, in others it is used with third and second person referents; but if the language allows logophoricity to be used with referents of a particular person, this use is obligatory.

A further potential difference is that the logophoric verbal affix of Gokana may be used with first person referents, although it is dispreferred. In general, logophoric pronouns and logophoric cross-referencing, at least, do not occur with first person referents [von Roncador 1992:166]. A few exceptions have been reported, but these are certainly not straightforwardly clear logophoric systems of the expected type. Thus, Wiesemann [1986:445] reports that the East Chadic language Lele has logophoric pronouns for all persons; however, here the forms are different for each person rather than a single logophoric pronoun used with referents of all persons (historically they consist of a speech introducer followed by the normal pronoun forms). The best candidate for a logophoric system used with first person referents is the Adamawa (Niger-Congo) language Yag Dii, which has a complex system where pronouns are marked for case, emphasis, and tense, and there are various sets of logophoric pronouns. Most commonly, the first person forms used in logophoric contexts are identical with the non-logophoric first person forms, while there is a distinct single form used for second and third person logophoric referents; in some cases there are special logophoric forms used only with first person (i.e., different forms are used with each person); however, with unmarked subjects a single, specifically logophoric pronoun is used with reference to all persons [Bohnhoff 1986:113].

And finally, while it is certainly the case that logophoric marking is not restricted in all languages to showing that a subordinate subject is coreferential with an argument in the matrix clause, if it can mark coreferentiality of a non- 
subject argument it is always clear which argument is coreferential-subject, object or possessive, for example. 5 This is not the case in Gokana, where the logophoric verbal affix simply indicates that some element in the subordinate clause is coreferential with the matrix subject or source, leading easily to ambiguities, as can be seen in example (22).

Gokana [Hyman \& Comrie 1981:24]

(22) lébàreè $k o$ aè div-èè e

Lebare said he hit-LOG him

'Lebare said he $_{i}$ hit him / Lebare $_{i}$ said that he hit him $_{i}$ '.

While none of these distinctions necessarily should be taken to imply that the Gokana logophoric verbal affix is not true logophoricity, it is clearly quite different in many of its behaviours from other types of logophoricity, even other types of verbal logophoricity, and should perhaps not be included with them in the develop-ment of typologies of logophoricity.

A system similar to that of Gokana, although perhaps not identical, is found in the related language Kana, described in Ikoro [1996]. Kana has a logophoric marker $-\grave{e}$, with various allomorphs, which occurs in the same sorts of environments with the same function as the Gokana $-E E$, with the contrast between its presence and absence in examples (23) and (24) patterning identically to the contrast seen in examples (20) and (21) in Gokana.

Kana [Ikoro 1996:283]

$(\grave{a}-) k j \quad k \bar{j} j \quad e ́-k \overline{11}$

he-say:FACT CONN he-DF-go

'he $\mathrm{i}_{\mathrm{i}}$ said that he $\mathrm{j}_{\mathrm{j}}$ would leave'

(24) (à-)kj̀ kjò̀ é-kīì-è

he-say:FACT CONN he-DF-go-LOG

'he $\mathrm{i}_{\mathrm{i}}$ said that he $\mathrm{i}_{\mathrm{i}}$ would leave'

However, rather than being a verbal suffix, this element in Kana is a clitic, and may occur in non-verbal subordinate clauses attached to other elements such as

5 Confusion of referents can arise when embedded speech is embedded under a further speech introducer in languages with logophoric pronouns-in some languages at least, in the most embedded speech either the "intermediate" or the "primary" speaker may be marked through logophoric pronouns. For example, in Koyra Chiini [Heath 1999:326], in the case of "X said to $\mathrm{Y}$ [Y said to $\mathrm{X}[\ldots \mathrm{X} \ldots \mathrm{Y} \ldots]$ ]', the most deeply embedded $\mathrm{X}$ and $\mathrm{Y}$ will both be marked as logophoric; $\mathrm{X}$ is marked as logophoric since $\mathrm{X}$ is the speaker of the first-order quotation, while $\mathrm{Y}$ is marked as logophoric since $\mathrm{Y}$ is the speaker of the second-order quotation. In this case, it is not possible to distinguish which argument in the most deeply embedded clause is which. It is, however, still possible to tell which argument (both) is coreferential, unlike in Gokana; it is simply impossible to distinguish which higher argument is being referred to by the logophoric pronouns. 
(27)

प̣̀-kà $\quad 6 u ̛ ́ \quad$ yá $\quad z e ̀$

3-said that.NON1 LOG.SG went

'He said that he (himself) went.'

\section{(28) î-kà bụ́ yá zè \\ 2-said that.NON1 LOG.SG went \\ 'You said that you went.'}

In fact, it is not entirely clear from the discussion whether $y a a^{\prime}$ should be treated as a verb prefix or a proclitic form; Clark [1972:102] notes that this form must occur immediately before the verb in these contexts, but writes it as a separate word and says that in these contexts no pronominal prefix occurs. He calls it an "emphatic reflexive pronoun" and translates it as 'self, himself/herself/itself', suggesting an identity of this logophoric element with the reflexive pronoun, which occurs in various other African languages [von Roncador 1992]. Unfortunately, Clark gives no examples of other uses of this marker, and it is thus unclear whether it is truly used as a reflexive pronoun, or whether Clark simply decided the best translation of this element in logophoric contexts was an emphatic with 'self' (cf. his translations in the above examples).

In addition to this use of the form yá in logophoric contexts, a verb suffix -mà also occurs in certain tense forms with second and third person logophoric subordinate verbs [Clark 1972:102]. While the use of this suffix is not further discussed by Clark, it is thus potentially a logophoric verbal affix, similar to that of Gokana, though it is restricted to particular tense forms and to second and third singular referents.

With plural referents, this emphatic reflexive pronoun $y a^{\prime}$ is not used, nor is the suffix - mà. Rather, a verb prefix $\grave{a}$ - occurs in second person plural and third person plural logophoric contexts (as seen in examples (29) and (30)), with or without a suffix -ni, although no examples are given with the suffix.

Ekpeye [Clark 1972:103-4, glosses added]

(29)

ù̀-kà-6è $6 u ̣$ à-zè

3-said-PL that.NON1 LOG.PL-went

'They said that they went.'
(30) í-kà-nì
$6 u ̛ ́$
à-zè
2-said-PL that.NON1 LOG.PL-went
'You people said that you went.'

This verb prefix $\grave{a}$ - is not only a logophoric marker, however; it is the usual first person exclusive form in matrix clauses. The addition of the suffix -ni converts it to the usual first person inclusive form. ${ }^{6}$ It is also used in cases where

\footnotetext{
6 Note that the verbal cross-referencing system of Ekpeye, excluding the logophoric marking, has four verb prefixes, marking $1^{\text {st }}$ singular, $2^{\text {nd }}$ singular, $3^{\text {rd }}$ singular and $1^{\text {st }}$ plural exclusive;
} 
the matrix and subordinate subjects are both first person (inclusive or exclusive), as in examples (31) and (32); here, of course, it is unclear whether the form is operating in its matrix clause fashion as first person plural, or in its logophoric sense.

Ekpeye [Clark 1972:103, glosses added]

à-kà méní à-zè

1P-said that.1 1P/LOG.PL-went

'We (exclusive) said that we went.'

(32) à-kà-nì méní à-zè-nì

1P-said-IN that.1 1P/LOG.PL-went-IN

'We (inclusive) said that we went.'

As mentioned above, no examples of the strictly logophoric use of the "first person inclusive" form are given, but Clark notes that the use of the suffix in subordinate logophoric contexts is "not obligatory, but rather depend[s] on the sense of the non-linguistic context" [Clark 1972:102]. While this is not entirely clear, presumably the absence or presence of the suffix in logophoric contexts carries the usual distinction, as shown in examples (33) and (34).

Ekpeye [Clark 1972:104, gloss added, parenthesized element added to translation]

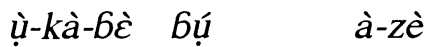

3-said-PL that.NON1 LOG.PL-went

'They said that they went (and the addressee was not part of the group).'

(34)

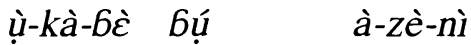

3-said-PL that.NON1 LOG.PL-went-IN

'They said that they went (and the addressee was part of the group).'

(Constructed example, suggested translation)

Thus, in Ekpeye the system of verbal logophoricity is of a combined typewith singular logophoric referents there is a system of logophoric cross-referencing (or perhaps a cliticized logophoric pronoun), together with what appears to be a logophoric verbal affix; while with plural logophoric referents there is a system of first person logophoricity (although the precise contrast in use between logophoric inclusive and exclusive first person plural is unclear). It is interesting to note that logophoric cross-referencing, like logophoric pronouns, has been found to occur with either both singular and plural referents or with singular referents only, the

a suffix $-6 \grave{\varepsilon}$ is used in conjunction with the $3^{\text {rd }}$ singular prefix to indicate $3^{\text {rd }}$ plural; and the suffix $-n i$ occurs with the $2^{\text {nd }}$ singular prefix to show $2^{\text {nd }}$ plural, and with the $1^{\text {st }}$ plural exclusive to indicate $1^{\text {st }}$ plural inclusive. 
situation found here; first person logophoricity in non-combined types of verbal logophoricity occurs with both singular and plural referents, but here with plural referents only, perhaps being ousted from referring to singular referents because of the existence of the logophoric cross-referencing system.

We turn to the two closely related Cross-River (Niger-Congo) languages, Efik and Ibibio, the former spoken in Nigeria, the latter in Nigeria and Cameroon. These languages have a verbal logophoric system which appears similar in many ways to that of Ekpeye. First, these languages have a system of verb prefixes which indicate the person of the subject. ${ }^{7}$ In singular logophoric contexts, with second and third person singular referents, a distinct verb prefix is used to signal logophoricity, as can be seen in examples (35), (36), and (37) from Efik.

Efik [Welmers 1968:118, glosses added]

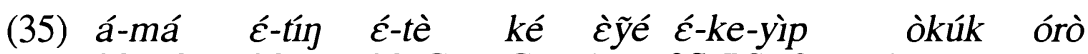
3S-PST1 3S-say 3S-CPL CPL he 3S-PST2-steal money DF

'He said that he (other) was the one who stole the money.'

(36) á-má ć-tín é-tè ké ìmo ì-ká-dá j̀wet fò

3S-PST1 3S-say 3S-CPL CPL LOG.SG LOG-PST2-take book your

ì-dí

LOG-come

'He said that he (self) was the one who brought your book.'

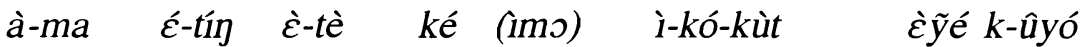

2S-PST1 2S-say 2S-CPL CPL LOG.SG LOG-PST2-see him in-Uyo

'You said you saw him in Uyo.'

Just as in Ekpeye, logophoric second and third person plural referents are indicated using the verb prefix which is used in matrix clauses to mark first plural subject, as can be seen in example (38) from Efik; that is, they appear to have a system of first person logophoricity (unlike Ekpeye, Efik and Ibibio do not distinguish inclusive versus exclusive). As in Donno So, which has logophoric pronouns and first person logophoricity, a logophoric subject pronoun may be present or absent, leaving the verbal logophoric marking as the only indication of logophoricity.

Efik [Welmers 1968:118, glosses added]

é-kère é-tè ké (mìms) ì-yé-dí

3P-think 3P-CPL CPL LOG.PL 1P/LOG-FUT-come tomorrow

'They think that they (selves) will come tomorrow.'

7 The system is extremely complex, with two different sets of affixes depending on whether the verb is neutral (set A) or negative/contrastive (set B), and different tones being used in complex ways for sequential verbs. 
There are, however, two differences between the Efik/Ibibio and Ekpeye systems of logophoricity. First, Efik and Ibibio also have logophoric pronouns, singular and plural, and these are not used when there is a first person referent as subject in both matrix and subordinate clauses, suggesting that in first person plural logophoric contexts, the "first person" verb morphology is indicating first person rather than logophoricity. 8

The more interesting difference is in the form of the verb prefixes in the singular and plural logophoric marking. In Ekpeye, the singular verbal logophoric marking is logophoric cross-referencing, with a special prefix, while the plural verbal logophoric marking is first person logophoricity, using the same morphology as matrix clause first person plural verbs. In Efik and Ibibio, the verb prefixes are identical for singular and plural logophoric referents, both thus being identical with first person plural marking. ${ }^{9}$ (The singular and plural logophoric pronouns are, however, distinct.)

It is thus unclear whether the verbal logophoric system of Efik and Ibibio should be treated as similar to that of Ekpeye, with logophoric cross-referencing in the singular and first person logophoricity in the plural. It is possible that historically the system of Efik and Ibibio was that of Ekpeye, but the singular logophoric cross-referencing prefix has fallen together with the first person plural prefix because of phonetic erosion (all verb prefixes are highly reduced forms). Alternatively, there may have historically been logophoric cross-referencing in both singular and plural (with distinct or identical forms), with phonetic erosion leading to phonetic identity between this logophoric cross-referencing prefix (or these number-marked logophoric cross-referencing prefixes) and first person plural marking.

We have thus seen that languages may have a single strategy for marking logophoricity-logophoric pronouns, logophoric cross-referencing, first person logophoricity, logophoric verb affixes-or may combine different strategies. Strategies which have been found are given in Table 1: logophoric verb affixes, logophoric cross-referencing and first person logophoricity with no logophoric pronouns, logophoric pronouns coextensive with logophoric cross-referencing, logophoric pronouns coextensive with first person logophoricity, logophoric crossreferencing in singular and first person logophoricity in plural with no logophoric pronouns, and possibly logophoric cross-referencing in singular and first person logophoricity in plural together with logophoric pronouns.

\footnotetext{
8 Of course, we have seen that logophoric pronouns and verbal logophoricity are distinct phenomena, and consequently could be operating here on distinct principles.

9 Only the Set A forms of the logophoric prefix are given in the descriptions, and this is identical to the Set A forms of the first person plural. The first person plural Set B form has a different tone; it would be interesting to discover whether the singular/plural logophoric Set B form is identical to the first person plural Set B form.
} 
Table 1: Combinations of verbal logophoric marking and logophoric pronouns (with sample languages)

\begin{tabular}{lll} 
& $\begin{array}{l}\text { No logophoric } \\
\text { pronoun }\end{array}$ & $\begin{array}{l}\text { Logophoric } \\
\text { pronoun }\end{array}$ \\
\cline { 2 - 3 } $\begin{array}{l}\text { Logophoric verb affix } \\
\text { Logophoric cross-referencing }\end{array}$ & Gokana & (none) \\
First person logophoricity & Akoose & Moru \\
$\begin{array}{l}\text { Logophoric cross-referencing (SG) and } \\
\text { first person logophoricity (PL) }\end{array}$ & Karimojong & Donno So \\
& Ekpeye & ? Efik
\end{tabular}

\section{Typologies of logophoricity}

As noted in section 2, there is general agreement in the typological literature on the broad definition of logophoricity, but there are some differences in the details. This section will discuss various definitions and what the existence of three different types of verbal logophoricity means for those discussions.

The most obvious impact of three types of verbal logophoricity on the typological literature has already been mentioned. Given that there are three types, and that each type appears to have somewhat different distributional possibilities, it is not at all clear that general implicational schemes such as those developed in Hyman and Comrie [1981] and Wiesemann [1986] — if logophoricity is used with plural referents, then it is used with singular referents; if logophoricity is used with second person, then it is used with first person, and so on-can be developed without taking into account that not all logophoric systems are the same. Three features of logophoricity appear to be particularly affected in this way: obligatoriness, use with first person, and combination with number.

In general, when a language has some device for marking logophoricity, this marking is obligatory when used to show that a subject (or object, if this is possible) of a subordinate clause is coreferential with an argument of a higher clause. 10 This obligatory nature of logophoricity is precisely one of the features which can be used to distinguish logophoricity from other systems such as nonclause-bounded or long distance reflexives [cf. Culy 1997]. Of course, logophoric marking may be restricted in person or number, only used with third person or only used with singular referents, but where it may occur, it must occur. This appears to be the case for all reported examples of logophoric pronouns, logophoric cross-referencing, and first person logophoricity; but it is not the case with verbal logophoric affixes in Gokana and Kana, where the system is optional with second and first person referents.

10 In some languages the system is also extended to use in other contexts, and in these contexts the system may be optional (see, for example, Culy [1994a]). 
Turning to the use of logophoricity with referents of different person, it is clear that logophoricity systems may be used with third person referents only, or with third and second person referents (see, for example, von Roncador [1992]). A few examples have been reported of the use of logophoric pronouns with first person, as noted above, although there are often additional complications in these systems. Once again, Gokana and Kana appear rather unusual, as the verbal logophoric affix is optionally used with first person referents. This unusual behaviour of a distinct type of logophoric system casts doubt on part of Hyman and Comrie's [1981] or Wiesemann's [1986] suggested logophoric implicational scale of $1>2>3$ (that is, that the use of logophoricity for first person referents implies that it is used for second person referents, which in turn implies it is used for third person referents): if the only clear evidence of the use of a logophoric system with first person is an entirely different type of system from the others, then it seems somewhat dubious to develop a scale on the basis of this evidence. Even accepting that first person logophoric marking occurs in Yag Dii, there is still an additional problem with the implicational scale, in that it does not quite hold true for Gokana; the logophoric verbal affix is used with first person plural but not for second person plural.

With regard to the implicational hierarchy that if logophoric marking is used with singular referents it is used with plural referents [e.g., Hyman \& Comrie 1981], this holds true but seems to miss an important point. Logophoric pronouns and logophoric cross-referencing are found to refer to singular referents only in some languages and singular and plural referents in other languages. There is even the case in Ekpeye, where the logophoric cross-referencing (or cliticized logophoric pronoun) is used in singular but not in plural. However, it does not hold for first person logophoricity, which does not seem to have this distribution. First person logophoricity is used with both singular and plural referents in all languages where it occurs, with the exception of Ekpeye (and possibly Efik and Ibibio), where it only occurs with plural referents, as logophoricity with singular referents is shown through logophoric cross-referencing. While the general statement that if some form of logophoric marking is used in plural then some form of logophoric marking is used in singular holds true (since some form of marking is used for both in Ekpeye), it seems more in line with the facts to say that if logophoric pronouns or logophoric cross-referencing is used with plural referents then the same strategy is used with singular referents; this restatement thus covers the use of logophoric cross-referencing with singular referents only in Ekpeye, and the fact that no examples have been reported where first person logophoricity occurs with singular but not plural referents.

One issue which arises in some of the typological literature with respect to logophoricity is the division of languages into "pure" and "mixed" logophoric languages, or "pure logophoric", "mixed logophoric", and "non-logophoric" languages. For Culy, pure logophoric languages are those in which there is some morphological and/or syntactic form (logophoric pronoun, addressee pronoun or verbal morphology) which is used only in logophoric domains, and mixed logophoric languages are ones in which "reflexive pronouns have an extended use in logophoric domains to refer back to the logophoric trigger" [1994a:1057]. 
According to Huang [2000:172-73], pure logophoric languages have special morphological or syntactic forms employed only in logophoric domains, nonlogophoric languages have no special morphology/syntax, and mixed logophoric languages where logophoric marking may be used for other purposes or reflexives may be used in logophoric contexts.

One general problem with these definitions is their framing in terms of languages, as a single language may contain elements of each type. For example, Culy [1994a] lists Moru as a pure logophoric language, with logophoric verbal marking, as it has special verbal affixes used only for marking logophoric contexts (although these have clearly derived from reflexive pronouns, according to Andersen \& Goyvaerts [1986]). However, Moru also uses reflexive pronouns in logophoric contexts, and thus according to Culy's definition, Moru is also a mixed logophoric language. This difficulty can, of course, be overcome by discussing pure and mixed logophoric constructions or elements, rather than languages.

A more serious problem with the definitions of pure and mixed logophoricity arises because of their non-exclusive nature, as can be seen by examining the three types of verbal logophoricity in terms of the division between pure and mixed. A verbal logophoric affix such as that of Gokana is clearly pure logophoricity, as it is apparently not used for anything else. Logophoric cross-referencing is also pure logophoricity, not otherwise used (but see below for further comment on the Moru, Kaliko and Logo systems). First person logophoricity, on the other hand, is clearly not pure logophoricity, as the form used to signal logophoricity is used elsewhere in the language as a marker of first person. This would imply that first person logophoricity is mixed logophoricity - but in fact given the definitions of Culy and Huang, it is not. Culy [1994a:1057] defines mixed logophoricity as the use of reflexive pronouns in an extended use, ${ }^{11}$ while Huang [2000:172-73] defines it as the use of reflexive pronouns or where logophoric marking is extended for other uses; and first person logophoricity is clearly neither of these.

Given Culy's [1994a, 1997] discussion, his division between pure and mixed logophoricity appears to be designed to distinguish the phenomenon of logophoricity from the distinct phenomenon of non-clause-bounded or indirect reflexives, as found for example in Japanese and Icelandic; an important and worthy goal. He clearly establishes that these two phenomena have distinct properties in terms of the discourse environments in which the two are used, their obligatoriness in situations of coreferentiality, and whether they are discourse-roleoriented [Culy 1994a:1079-82]. Given that these phenomena, which are conflated in some discussions, have different properties, it is important to distinguish them. However, whether a particular logophoric-like form and construction have the properties of logophoric pronouns or indirect reflexives is a quite distinct issue from whether the form which is used in these constructions is employed somewhere else in the grammar for a different purpose (although an examination

11 It must be noted that shortly after his definition of mixed logophoricity as relating to reflexive pronouns, he goes on to give as his first example of a mixed logophoric language the Kwa language Yoruba, where the forms used for logophoric marking are the "long forms" of the pronouns, which are used as independent, non-reflexive, pronouns. 
of strictly single-use forms may be of great assistance as the initial step in establishing the respective properties of the phenomena). Indeed, with regard to at least two of the three properties in question, first person logophoricity lines up with logophoricity rather than with indirect reflexives-first person logophoricity is used in the discourse environments of logophoricity, and is obligatory under these conditions. Whether or not first person logophoricity is discourse-roleoriented is unknown.

This distinction of logophoricity on the basis of its properties rather than on the form used also avoids potential problems of deciding whether two forms are the "same" or "different". For example, as seen in example (6), Kaliko has a logophoric cross-referencing verb prefix yí-, and this appears to have the expected properties of such marking (e.g., used in appropriate environments, obligatory). This prefix is never used as a reflexive marker; reflexives cannot be subjects. However, it is clearly related historically to the pronoun $y \bar{I}$, and has the same morphophonemic relation to it that first and second person verbal prefixes have to the corresponding pronouns [Andersen \& Goyvaerts 1986:311]. The pronoun $\bar{y}$ is used everywhere except directly before a verb, as are other pronouns. In particular, it is used in logophoric contexts when the subordinate clause is nonverbal, as in example (39).

Kaliko [Andersen \& Goyvaerts 1986:311]

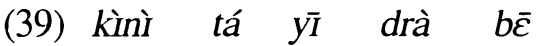

3S.say CPL LOG illness with

'He $\mathrm{H}_{\mathrm{i}}$ said that he $\mathrm{i}_{\mathrm{i}}$ was ill.'

However, while we may thus wish to say that $y \bar{I}$ is the equivalent of the logophoric cross-referencing prefix used when there is no immediately following verb, the pronoun $y \bar{I}$ is identical in form to the reflexive pronoun in Kaliko. ${ }^{12}$ Disallowing this pronoun as a representative of pure logophoricity would thus lead us to report that in Kaliko there is a system of pure logophoricity when the subject of a subordinate clause is coreferential with the matrix subject and there is a subordinate verb, but a system of mixed logophoricity when the subject of a subordinate clause is coreferential with the matrix subject but there is no subordinate verb. And we would have to decide at which point during the grammaticalization of the pronoun into a clitic then into a prefix that the system had suddenly changed from one of mixed logophoricity to one of pure logophoricity.

Of course, whether a logophoric form is identical to, similar to, or historically derived from some other form (reflexive or not) is of interest in examining the origins of logophoricity and paths of grammaticalization-but it should not be used as a defining feature of logophoricity, since some "mixed" logophoricity seems to have the properties of "pure" logophoricity rather than the properties associated with indirect reflexivization. 
Rather than establishing a division between pure and mixed logophoricity on the basis of whether the particular form is used in other contexts, then, it seems more appropriate to divide up logophoricity (and distinguish it from indirect reflexivization) on the basis of the properties of the particular phenomenon in question.

\section{Conclusion}

Verbal logophoricity in African languages is indicated using three separate devices: logophoric cross-referencing, first person logophoricity, and logophoric verbal affixes. In some languages, more than one of these devices may be used, depending on features of the referent, such as person and number, and verbal logophoricity may be found alone or combined with logophoric pronouns, as was seen in Table 1.

While all three types share certain features (such as their use in logophoric domains, when an utterance is subordinated to a verb of speech), they have distinguishing properties also; these properties are exemplified in Table 2 , which also includes the properties of logophoric pronouns and indirect reflexives. ${ }^{13}$

Given that each of these types of verbal logophoricity would appear to have different properties, it is important to keep them distinct from each other and from logophoric pronouns in general discussions of typological features of logophoricity, at least until it is determined on the basis of further research whether the properties truly are different or simply appear distinct because of a current lack of data.

13 Logophoric addressee pronouns, clearly related, have not been included here. 
Table 2: Properties of different types of verbal logophoricity

(a semicolon indicates that a language may have either one or the other property)

\begin{tabular}{|c|c|c|c|c|c|}
\hline & $\begin{array}{l}\text { Logophoric } \\
\text { cross-referencing }\end{array}$ & $\begin{array}{l}\text { First person } \\
\text { logophoricity }\end{array}$ & $\begin{array}{l}\text { Logophoric } \\
\text { verb affix }\end{array}$ & $\begin{array}{l}\text { Logophoric } \\
\text { pronoun }\end{array}$ & $\begin{array}{l}\text { Indirect } \\
\text { reflexivization }\end{array}$ \\
\hline Obligatorya & yes & yes & yes $b$ & yes & no \\
\hline Marked on & $\operatorname{verb}^{c}$ & verb & verb & pronoun & pronoun \\
\hline In person paradigm ${ }^{d}$ & yes & yes & no & yes & yes \\
\hline Special forme & yes $^{f}$ & no & yes & yes; no & no \\
\hline Persong & 3 only; $2+3$ & $2+3 ; 3$ onlyh & $(1+2+) 3^{i}$ & 3 only; $2+3 ; 1+2+3 j$ & 3 only \\
\hline Number & $\mathrm{sg} ; \mathrm{sg}+\mathrm{pl}$ & $\mathrm{sg}+\mathrm{pl} ; \mathrm{pl}$ & $\mathrm{sg}+\mathrm{pl}$ & $\mathrm{sg} ; \mathrm{sg}+\mathrm{pl}$ & $\mathrm{sg}+\mathrm{pl}$ \\
\hline
\end{tabular}

Notes to table 2:

a. That is, whether the logophoric form is obligatory at least in embedded speech contexts.

b. The logophoric affix in Gokana and Kana is obligatory only with third person.

c. Some cases are intermediate between logophoric verb marking (with affix) and logophoric pronouns, with pronouns cliticized to the verb.

d. That is, does the logophoric form contrast with (other) person-marked forms.

e. That is, does the logophoric marker have other functions as well.

f. The logophoric cross-referencing forms of Moru, Kaliko and Logo are clearly related to and historically derived from the reflexive pronouns.

g. Here it is important that the same form be used for different persons.

h. There are languages for which the only examples of first person logophoricity are found with third person referents; however, it is not clear whether these forms cannot be used with second person referents, or are simply not exemplified.

i. The logophoric verbal affix of Gokana is found with all persons, but is obligatory with third person only.

j. The only clear example of the use of a logophoric pronoun used with second and third person also being used with first person is Yạg Dii, and apparently some related Adamawa languages [Bohnhoff 1986]. 


\section{REFERENCES}

Andersen, Torben. 1999. "Anti-logophoricity and indirect mode in Mabaan." Studies in Language 23(3):499-530.

Andersen, Torben and Didier L. Goyvaerts. 1986. "Reflexivity and logophoricity in Moru-Madi.” Folia Linguistica 20(3/4):297-318.

Bohnhoff, Lee E. 1986. "Yạg Dii (Duru) pronouns.” In Ursula Wiesemann (ed), Pronominal Systems (Continuum 5). Tübingen: Gunter Narr. pp 103-129.

Clark, David J. 1972. "A four-term person system and its ramifications." Studies in African Linguistics 3(1):97-105.

Clements, George N. 1975. "The logophoric pronoun in Ewe: Its role in discourse." Journal of West African Languages 10(2):141-177.

Culy, Christopher. 1994a. "Aspects of logophoric marking." Linguistics 32:10551094.

Culy, Christopher. 1994b. "A note on logophoricity in Dogon." Journal of African Languages and Linguistics 15:113-125.

Culy, Christopher. 1997. "Logophoric pronouns and point of view." Linguistics 35(5):845-859.

Dimmendaal, Gerrit J. 2001. "Logophoric marking and represented speech in African languages as evidential hedging strategies." Australian Journal of Linguistics 21(1):131-157.

Hagège, Claude. 1974. "Les pronoms logophoriques." Bulletin de la Société de Linguistique de Paris 69:287-310.

Heath, Jeffrey. 1999. A Grammar of Koyra Chiini: The Songhay of Timbuktu. Berlin: Mouton de Gruyter.

Hedinger, Robert. 1981. "Pronouns in Akoose." Studies in African Linguistics 12(3):277-290.

Hedinger, Robert. 1984. "Reported speech in Aksose." Journal of West African Languages 14(1):81-102.

Heine, Bernd and Mechthild Reh. 1984. Grammaticalization and Reanalysis in African Languages. Hamburg: Buske. 
Huang, Yan. 2000. Anaphora: A Cross-Linguistic Study (Oxford Studies in Typology and Linguistic Theory). Oxford: Oxford University Press.

Hyman, Larry M. and Bernard Comrie. 1981. "Logophoric reference in Gokana." Journal of African Languages and Linguistics 3(1):19-37.

Hyman, Larry M. and Bernard Comrie. 1982. "Coreference and logophoricity in Gokana." In William R. Leben (ed), Précis from the Twelfth Conference on African Linguistics, Stanford, April 10-12, 1981 (Studies in African Linguistics, Supplement 8). Los Angeles: Department of Linguistics, UCLA. Pp 69-72.

Ikoro, Suanu M. 1996. The Kana Language (CNWS Publications 40). Leiden: Research School CNWS.

Muratori, C. 1938. Grammatica Lotuxo. Verona: Missioni Africane.

Novelli, Bruno. 1985. A Grammar of the Karimojong Language (Language and Dialect Studies in East Africa 7). Berlin: Reimer.

Reinhart, Tanya and Eric Reuland. 1991. "Anaphors and logophors: An argument structure perspective." In Jan Koster and Eric Reuland (eds), Long-Distance Anaphora. Cambridge: Cambridge University Press. Pp 283-321.

Reuland, Eric. 2001. "Anaphors, logophors, and binding." In Peter Cole, Gabriella Hermon, and C.-T. James Huang (eds), Long-Distance Reflexives (Syntax and Semantics 33). San Diego: Academic. Pp 343-370.

von Roncador, Manfred. 1992. "Types of logophoric marking in African languages." Journal of African Languages and Linguistics 13:163-182.

Welmers, William E. 1968. Efik (Occasional Publication 11). Ibadan, Nigeria: Institute of African Studies, University of Ibadan. (Original manuscript 1966, produced at Lutheran Mission Obot Idim, Uyo.)

Wiesemann, Ursula. 1986. "Grammaticalized coreference.” In Ursula Wiesemann (ed), Pronominal Systems (Continuum 5). Tübingen: Gunter Narr. Pp 437-463.

21/68 Gladstone Road

Highgate Hill QLD 4101

Australia

tjcurnow@ozemail.com.au
[Received September 2002; accepted November 2002] 
